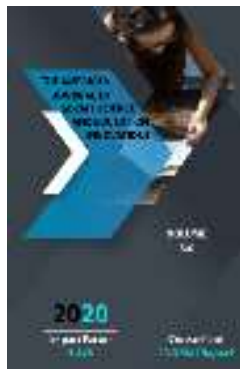

Journal Website: http://usajournalshub.c om/index,php/tajssei

Copyright: Original content from this work may be used under the terms of the creative commons attributes 4.0 licence.

\section{The Importance Of Improving The Spiritual Basis Of Civil Society Institutions In Society}

\author{
Zokir Zamonov \\ Doctor Of Philosophy In Political Science (Phd) Department Of Social Sciences Uzbekistan \\ State World Languages University, Uzbekistan \\ Zulayho Ibotova \\ 4th Year Student, Faculty Of Foreign Languages, Uzbekistan State World Languages \\ University, Uzbekistan
}

\title{
ABSTRACT
}

This article reveals the peculiarities of the development of socio-spiritual aspects of civil society institutions in the organization of their activities and their integration into today's practical life, as well as the integration of state and non-governmental organizations to improve the spiritual basis. It also analyzes the effective actions of civil society institutions in the interests of human dignity, as well as the interests of the state and society.

\section{KEYWORDS}

Civil society institutions, spiritual foundations, public organizations, human interests, social policy, integration processes, practical actions.

\section{INTRODUCTION}

In the first period of independence, the organization and support of public organizations based on democratic principles were developed. In particular, the adoption of the first legislative act on institutions in
Uzbekistan on February 15, 1991 - the Law "On Public Associations" - proved the expansion of work in this area, the development of society on the basis of certain social institutions. Shortly after independence, the development 
of a legal framework for the free operation of such organizations determined the role of the state in the development of our society and the interests of citizens through the subsystems of society. This shows that the foundation of positive processes in the field of legal regulation of civil society institutions, sociocultural organizations has begun to be laid in our country. It should be noted that the law adopted in 1991, for the first time, gave a legal definition to the institution of public association (organization), as well as the purpose, principles of its activities, the scope of rights and obligations [1].

In particular, according to Article 1 of this Law, political parties, mass movements, trade unions, women's, youth and children's organizations, veterans' and disabled people's organizations, scientific-technical, culturaleducational, physical culture-sports and other voluntary societies, creative unions, civic associations, and other associations of citizens became public associations.

\section{MATERIALS AND METHODOLOGY}

In particular, Chapter XIII of the Constitution of the Republic of Uzbekistan [2] devoted to the activities of public associations, provided full independence of such organizations from public authorities, on the other hand, was the basis for the correct and effective determination of their activities.

In particular, Article 56 of the Constitution states that "trade unions, political parties, societies of scientists, women's, veterans' and youth organizations, creative associations, mass movements and other associations of citizens registered in the Republic of Uzbekistan are recognized as public associations" [3], put.
In recent years, the country has created a political and legal framework to support and improve the activities of such institutions that fully protect the interests of citizens. For example, "On Public Associations in the Republic of Uzbekistan”, “On Trade Unions, Guarantees of Their Rights and Activities", "On Non-Governmental Organizations", “On Citizens' Self-Government Bodies", “On Political Parties" [4], This is confirmed by the Law on Public Funds and a number of other laws.

Also this year, the Law "On Public Associations in the Republic of Uzbekistan", "On Freedom of Conscience and Religious Organizations", "On Political Parties", "On Protection of Journalism", "On Mass Media", "Information The amendments to the Law on the Principles and Guarantees of Freedom" have created a sufficient basis for their decision-making and practical initiatives in the government to achieve a certain result.

\section{RESULTS AND DISCUSSION}

It should be noted that the enterprise, organization, institution performs two important functions in its activities. The first is production: the creation of products, material things, and the second is to engage in sociospiritual work. A particular organization operating in the country on a systematic basis as a civil society institution, the spiritual and cultural activities carried out by the community play an important role in their genesis, development and organizational and legal framework. 
Picture $1[5]$.

\section{Civil society institutions operating in the country today.}

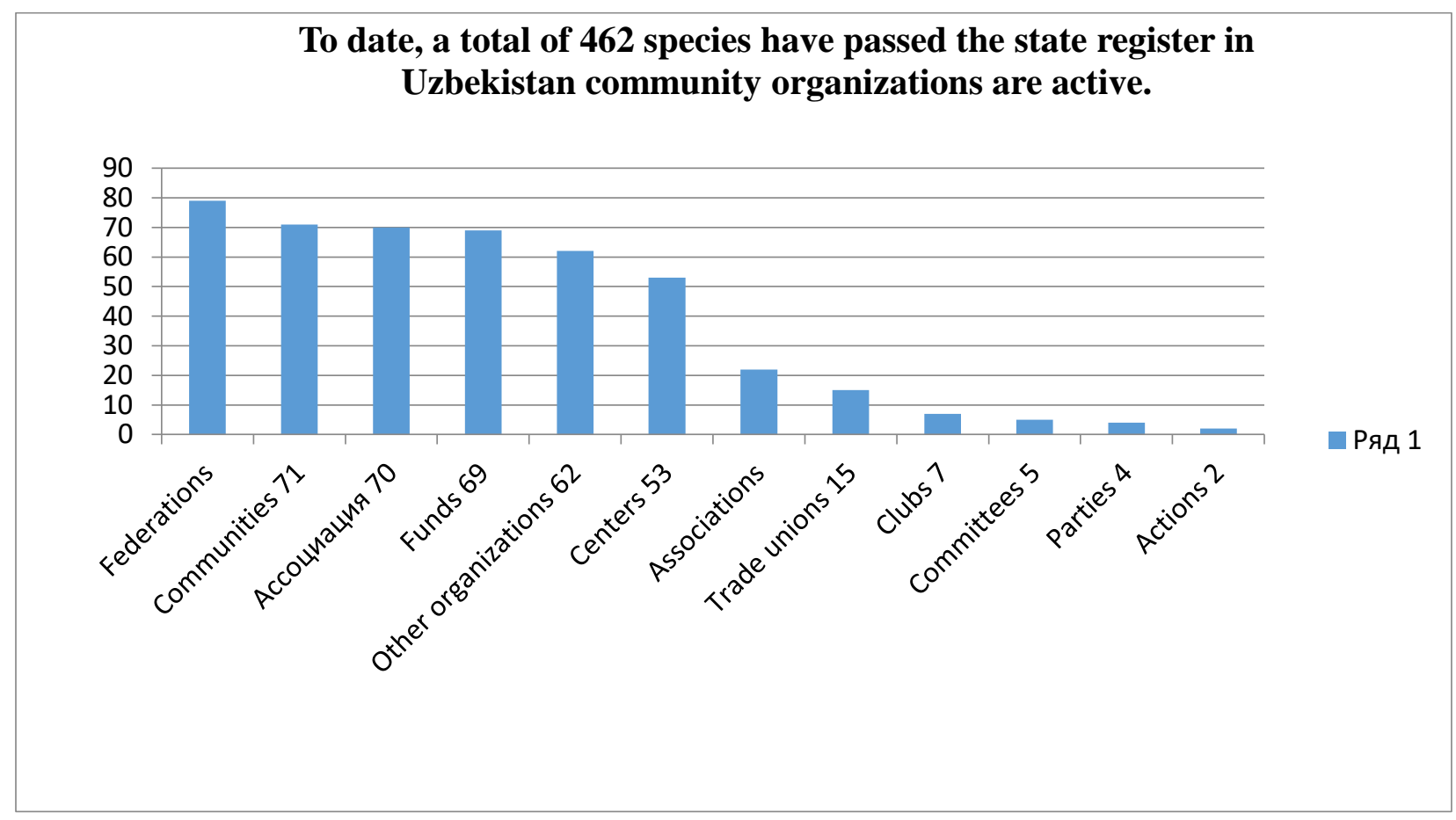

Naturally, there are several types of public organizations currently operating, which can be divided into: political movements, women's and youth support organizations, the Enlightenment Foundation, cultural and educational institutions, and other types of voluntary organizations.

Political scientist M. Kyrgyzbaev notes that interest groups, which take the form of institutionalized social groups, are called by different names in different countries based on their historical experience and traditions. For example, in the United States, interest groups are called civic institutions, volunteer organizations, common interest groups, pressure groups, while in the West they are called NGOs, charities, foundations [6].
An important function of associations, which takes the form of interest groups, is to integrate interests. This means bringing the interests of another group closer together with different social groups that operate on the basis of the interests of their members outside of certain social groups. In this process, agreements are made between different groups, and social agreements and compromises are strengthened [7].

In our country, in the post-independence period, such organizations have been divided into the number of categories and began to operate under the name of public organizations, non-governmental non-profit organizations, socio-cultural institutions, foundations and associations. 
In addition, in today's developed countries, social organizations, in particular nongovernmental non-profit organizations, are engaged in activities that are not related to politics, such as trade unions, to help the population in need of social protection. For example, NGOs in the United States are funded by individuals, private-sector commercial companies, charitable foundations, membership fees, or federal and local governments (grants) [8]. The development of these organizations can be directly understood as the free movement of civil society institutions.

In particular, special attention was paid to the creation of a legal framework for the activities of such institutions. At the same time, the freedom of association of public and nongovernmental non-profit organizations was exercised within certain limits. However, it was clearly stated that this right could not be used for anti-social purposes.

In particular, according to the Constitution, it seeks to forcibly change the constitutional order, opposes the sovereignty, integrity and security of the republic, the constitutional rights and freedoms of citizens, promotes war, social, national, racial and religious hatred, encroaches on the health and spirituality of the people, the legal prohibition of the formation and operation of militarized associations, political parties and public associations of national and religious spirit, as well as the formation of secret societies and associations [9]. This, in turn, determines the status of public associations to establish effective relations with public administration and active associations within the institute of civil society. Indeed, the activities of public associations are closely linked to state power. Both entities cooperate as important institutions of the political system in ensuring socio-political stability and balance in society [10].

For a quarter of a century, the number of public organizations, non-governmental organizations, and civil society development institutions in our country has been growing and developing year by year. As a result, if as of January 1, 1991, the number of nongovernmental non-profit organizations was 95, by the end of 2016 their number had increased several thousand times and reached 8,700 . By 2018, there will be 530 women's nongovernmental organizations, about 10,000 citizens' self-government bodies, as well as more than 9,000 non-governmental non-profit organizations, branches and representative offices of 29 international and foreign nongovernmental organizations [11].

In addition, the country has adopted more than 200 pieces of legislation aimed at increasing the role and importance of civil society institutions in addressing pressing socioeconomic problems of citizens. In particular, the adoption of the Decree of the President of the Republic of Uzbekistan on May 4, 2018 "On measures to radically increase the role of civil society institutions in the democratic renewal of the country" and the establishment of the Advisory Council on Civil Society Development under the President of Uzbekistan brought to the stage.

Given that not only the number but also the quality of civil society institutions is growing, "at the new stage, along with expanding the ranks of such organizations, it is planned to sharply strengthen their role and status in society," [12] said academician A.Saidov.

As a result of the transfer of a number of management decisions to the lower levels, selfgovernment, self-sufficiency is realized. In this 
regard, more than 30 tasks related to the competence of local authorities were gradually transferred to the mahallas [13].

In addressing the issues of social priority in society, it is necessary to strengthen cooperation between local authorities and state and public organizations, to strengthen the coordination of service systems within their competence. At the same time, the role of non-governmental non-profit organizations in understanding and expressing the identity of our people shows that the development of such institutions is expedient.

The emergence of non-governmental organizations as institutions that allows to demonstrate self-awareness is their:

Voluntary organization;

Mass character;

Have clear goals and objectives;

Focus on socio-constructive activities;

Legitimacy [14];

V.Kuchkarov, a political scientist, argues that it reflects such an activity as an alternative force to the state, such as social control over its institutions.

In this sense, they make a valuable contribution to the development strategy of the country, the education of the population, the nation, the formation of such qualities in society as justice, kindness, love, cooperation, humanity.

It should be noted that the role and place of non-governmental non-profit organizations in the ongoing reforms to build a free civil society and protects human rights and freedoms is invaluable, said President Mirziyoyev.

Any organization is formed and operates primarily on the basis of national interests. Today, in a sense, Sector 3 - non-governmental non-profit organizations - also carry out spiritual activities, such as the understanding of national identity, the development of national ideas and ideologies and their promotion to the general public [15]. It is they who, in a sense, create a spiritual-moral, social space with the many measures they take.

In this sense, public organizations operating in our country, based on their mission, also perform the function of studying and promoting the spiritual and cultural heritage. They are the main intermediary organizations for the transmission of historical and cultural heritage, the accumulated experience from ancestors to generations, as civil society, interests, institutions. In addition, any public organization is an organizational unit based on political and legal norms, an institution with the status of an institution with organizational goals, tasks, methods and tools, certain functions.

The normative and legal framework developed for the organization and improvement of the activities of civil society institutions for more than a quarter of a century has led to an increase in the activities and socio-spiritual activity of public organizations as a result of the rapid development of the moral foundations of civil society institutions. As a result, the moral foundations of civil society institutions provide a basis for the implementation of the strategic action plan in accordance with regulatory requirements.

\section{CONCLUSIONS}

This can be justified as follows:

First, it is based on the certain criteria for the formation and implementation of public organizations. The criteria on which it is based stem spontaneously from the ideology of society. The voluntary, voluntary membership 
of every citizen in a particular organization, the freedom of a particular organization to operate without going beyond the bounds of the law, also draws strength from the principles of the national idea;

Second, as a result of attention to the spiritual and social direction of practical activities in the country's politics, decision-making in the life of society based on the national mentality and the real implementation of national ideology went hand in hand with socio-political processes. This, in turn, was seen as one of the important conditions for democratic reforms in the understanding of national identity and the widespread assimilation of the national idea in all spheres;

Third, the attitude of the state and society towards spiritual issues has changed radically [16]. The state was appointed as the chief reformer of spiritual reforms. This, in turn, demonstrates that civil society institutions are an effective institution in public administration to develop human spirituality and bring it to the forefront;

Fourth, the factors that promoted the political, social, economic formation of society in terms of development and the provision of all constitutional rights and interests of citizens also directly affected the development of the spiritual foundations of society. Also, the spiritual and ideological interest became more concrete over the years.

\section{REFERENCES}

1. Law of the Republic of Uzbekistan No. 223XII of February 15, 1991 "On Public Associations in the Republic of Uzbekistan" // Bulletin of the Supreme Council of the Republic of Uzbekistan. 1991. -№4. - Article 76.
2. Seven articles of the Constitution of the Republic of Uzbekistan, ie Articles 56-62, are devoted to public associations.

3. The Constitution of the Republic of Uzbekistan. -T .: Uzbekistan, 2015. -p. 19.

4. [Electronic source]: www.lex.uz.

5. Official site of the Ministry of Justice of the Republic of Uzbekistan: [Electronic source] http://www.minjust.uz/ru/interactive/nnt/3 $89 / 3144$

6. Kyrgyzbaev M. Civil society: genesis, formation and development. $-\mathrm{T}$ : Uzbekistan, 2010. - pp. 172-173.

7. Haywood E.. Political science. Textbook. Per. $s$ angl. -M .: UNITI-DANA, 2005. - pp. 344-355.

8. History of NKO in the USSR Blog posolstva SSHA in Moscow http://embassyvoices.livejournal.com/19048 .html.

9. The Constitution of the Republic of Uzbekistan. - T .: Uzbekistan, 2015. -B. 19.

10. E.T.Tojiev, Sh.G'.Asadov. Public control over the activities of public authorities and administration. -T .: Akademiya, 2013. - p. 93.

11. Address of the President of the Republic of Uzbekistan to the Oliy Majlis. "Khalq so'zi" newspaper, December 23, 2017 issue.

12. Saidov A.X. On the way to the formation of civil society. People's Word, September 11, 2002.

13. Eshboev R. Legislation on nongovernmental non-profit organizations is a guarantee for their effective operation. [Electronic source]: www.minjust.uz.

14. Kochkarov V. Awareness of national identity and sustainable development. $-\mathrm{T}$ : Akademiya, 2012. B 127. Address of the President of the Republic of Uzbekistan Shavkat Mirziyoyev to the Oliy Majlis. 12/22/2017 Official website of the President of the Republic of Uzbekistan: URL: http: //preresent.uz/en/lists/view/1371. 
Doi: https://doi.org/10.37547/tajssei/Volume02Issue08-40

15. Existing organizations in the country are divided into three sectors. Sector 1 government organizations and institutions, Sector 2-organizations operating in various socio-economic areas, Sector 3 - nongovernmental non-profit organizations.

16. Mavlonov O., Abduvosidova I. Historical and cultural heritage is a factor in understanding the national idea. Academy of Public Administration under the President of the Republic of Uzbekistan. Committee for Coordination of Science and Technology Development under the Cabinet of Ministers of the Republic of Uzbekistan. $-T$ .: Akademiya, 2014. - p. 152. 